\title{
Influence of Human Capital on Economic Growth: A Comparative Analysis of Education Development in Kazakhstan, South Korea, Singapore and Malaysia
}

\author{
Assel Shaimerdenova \\ Ministry of Labor and Social Protection \\ Astana, Kazakhstan \\ Jean-Claude Garcia-Zamor (Corresponding author) \\ Florida International University, Miami, Florida, United States \\ E-mail: garciazamor@hotmail.com
}

Received: June 12, 2017 Accepted: June 28, 2017 Online published: July 10, 2017

doi:10.5296/jpag.v7i3.11521ＵRL: https://doi.org/10.5296/jpag.v7i3.11521

\begin{abstract}
This research paper aims to conduct a comparative analysis of human capital in Kazakhstan and South Korea, Singapore, and Malaysia. In 1997 the president of Kazakhstan announced in his "Program for Strategic Development of Kazakhstan until 2030" that the country by 2030 will be one of the developed countries in the world such as the "Asian Tigers" - South Korea, Singapore, and Malaysia. Thus, the research paper seeks to determine the level of economic development and human capital of Kazakhstan compared with those countries. The paper discusses the situation in South Korea, Singapore and Malaysia in order to find directions for economic improvements in Kazakhstan through developing human capital. After reviewing the education development of Korea, Singapore and Malaysia and the state of the economy and education in Kazakhstan, it concluded that it is crucial for Kazakhstan to develop its human capital in order to turn the country into a diversified, highly productive economy and to reach its goal of joining the top-30 developed countries in the world.
\end{abstract}

Keywords: Economic development, human capital, Education development, Literature review. 


\section{Introduction}

Many economists and practitioners recognize that human capital is one of the important factors that influences the economic development. Some other factors also affect economic growth, such as geographic endowments, historical preconditions, institutions, political regimes, government policies, property rights, political accountability, total factor productivity etc. Easterly \& Levine (2001) state that human capital might not explain economic performance, and wrote that "after physical and human capital accumulation are accounted for, total factor productivity accounts for the bulk of cross-country differences in the level and growth rate of gross domestic product (GDP) per capita" (p. 178). Another way to think about it is that Cuba for example, has high human capital relative to other countries at the same level of economic development, as did much of Eastern Europe. Institutions and economic policy choices may serve to harness human capital and produce growth or ignore it and leave growth stagnant.

In addition, Glaeser, et al. (2004) debated about "whether political institutions cause economic growth, or whether, alternatively, growth and human capital accumulation lead to institutional improvement." The study finally found that "human capital is a more basic source of growth than are the institutions" (p. 1). The difference between macro-economic and micro-economic growth could be important to examine. Human capital accumulation in small industries might not boost national growth and concentrated income due to human capital increases in certain areas, such as high-tech industries, might not lead to higher median incomes in large, unequal countries.

International organizations such as the World Economic Forum and the United Nations claim that human capital is critical for economic growth because human capital is important not only to the high performance of society but also for political, social and civic institutions. Also, many scholars emphasize that human capital in South Asian countries is a center factor that contributed to economic and social development (EFA: Singapore and Korea, 2015).

This research paper aims to conduct a comparative analysis of human capital in Kazakhstan and South Korea, Singapore, and Malaysia. In 1997 the president of Kazakhstan announced in his "Program for Strategic Development of Kazakhstan until 2030" that the country by 2030 will be one of the developed countries in the world such as the "Asian Tigers" - South Korea, Singapore, and Malaysia. Thus, the research paper seeks to determine the level of economic development and human capital of Kazakhstan compared with those countries. The paper analyzes the situation in South Korea, Singapore and Malaysia in order to find directions for economic improvements for Kazakhstan through developing human capital.

Human capital is a complex idea that took various times for many scientists to identify different approaches to measuring it. In the literature review section, the paper will discuss the importance of human capital and methods of its measurement. Next, the paper continues by describing the origins of the data and variables such as Human Development Index and Gross National Income per capita (purchasing power parity). The one notable fact that appeared from the analysis is that growth in Human Development Index effects the GNI per 
capita. Because education is significant to the development of human capital, the next section proceeds with a brief summary of education development in Korea, Singapore, and Malaysia. Further, the paper discusses the challenges in management education and development in Kazakhstan. In conclusion, the paper deliberates recommendations that Kazakhstan should implement in order to enhance its human capital by transforming to the knowledge based economy, improving quality of education, creating more research universities, and developing human resource management.

\section{Literature Review}

Most academia agree that human capital is supreme in economic development. According to Bean (2016) the most valuable factor of a long-term economic success that is more valuable than any other resource is strong human capital based on high level knowledge and skills that entail development of a country's economy (p. 104). Moreover, human capital is more important than institutions and democracy. For example, Glaeser, et al. (2004) examined the level of schooling, political institutions and GDP per capita in 5-year intervals. The research demonstrated "a large and positive effect of initial level of income on the growth of education," however there were no effects of political institutions on the growth of human capital. Also, the authors observed political institutions, levels of schooling, levels of economic growth in 5-year intervals and detected a positive correlation between levels of schooling and institutional development. The research proved that human capital influences growth. Then greater human capital than greater institutional growth. Countries that were initially poor could build strong human capital under dictatorships, after increasing their institutions (pp. 297-298). Thus, the research showed that human capital affects economic growth through institutional improvement.

To measure human capital Mincer (1974) created a model for measuring human capital through school attainment. The model measures human capital by how much schooling an individual has completed which means that by attending school, an individual obtains the general skills and helps to maintain high literacy rates among the population. School attainment is very important, and always measures and reflects the education level of the population. Therefore, human capital is often associated with school attainment. Further, Mincer analyzed the differences in wages between people who were educated and not those who were not. People who attained school earn greater wages than people who did not attain school.

According to Hanushek (2013) the center part of the strategic development for most countries was school development. The World Bank Data demonstrates significant enhancement in school attainment in the developing world for the last twenty years. The increasing government attention on schooling has reflected on the strength of human capital. However, simple school attainment does not guarantee growth and development.

Cognitive skills play a more important role in people's earnings than simple school attainment. Cognitive skills effect the income distribution and more significantly influence economic growth. The research of Hanushek \& Woessmann (2011) demonstrates evidence of the role of school quality in economic development. To determine the quality of schooling 
among countries there were two sources of assessments: Trends in Mathematics and Science Study (TIMSS) created by the International Association for the Evaluation of Educational Achievement (IEA) in 2011 and The Program of International Student Assessment (PISA) produced by the Organisation for Economic Cooperation and Development (OECD) in 2000. The tests measure skill differences among countries. Skills as measured by achievement and the result on the science and math tests can be used as a direct indicator of the human capital of a country. The model shows that including direct assessments of skills school attainment does not affect the growth, and the coefficient on school attainment is almost zero. Therefore, the authors suggest that the results of the international assessments in mathematics and science are closely related to the distinction of countries in terms of economic growth.

There is a difference in quality of schools among countries. For instance, in order to evaluate school quality, UNESCO (2006) has included pupil/teacher ratio, percent of female teachers, percent of trained teachers, government expenditures on primary education, and government expenditures per student on primary education. However, studies that have examined educational performance in developed and developing countries, have demonstrated little relationship between these measures and student achievement (Hanushek, 2013).

Hanushek \& Woessmann (2012) state that during the 1980s and 1990s countries with more skilled employees had rapid growth in industries that required skill-intensive workforce. This proves that more skilled people allows faster use of innovative technologies and improvement in production processes which leads to technological dispersion and development.

Another question examined by Hanushek (2013) was "should policy focus on basic skills or the higher achievers? Should developing countries work to expand their higher education sector?" The study indicated that basic and advanced skills are important, specifically for developing countries. Another impressive fact was that the amount of tertiary education has no significant effect on economic development. The data also revealed the deficit of a skilled lobar force in developing countries. The author asserted that in order to decrease the economic gap, developing countries should pay serious attention to "structural changes in schooling institutions" (p. 204-205).

Also Hanushek (2013) argues that measuring countries human capital by school attainment is complicated. It is unrealistic to compare a year of school in developed countries with a year of school in Africa, for example. Moreover, Hanushek disputes the measurement of human capital considering schooling as the only source of human capital and skills. There is another way to enhance human capital by improving health and nutrition (p. 209).

International organizations that seek remedies to improve life conditions in the world designed their own measurement for the human capital. For instance, the World Economic Forum elaborated The Human Capital R, a complex measurement approach for measuring the human capital across countries and their workforce. These two categories show how the country takes advantage of its human capital and how well prepared it is to compete in globalized economy. 


\section{$\triangle$ Macrothink}

Journal of Public Administration and Governance

ISSN 2161-7104

2017, Vol. 7, No. 3

The Human Capital Index 2013 provides country rankings and explores the level of health, education and productive work force. The Index 2013 contains 51 indicators divided into the four pillars such as education, health and wellness, workforce and employment, and the enabling environment. The education pillar is dependent on access to and quality of education, as well as educational attainment across primary, secondary and tertiary levels. The health and wellness pillar measures an average life expectancy across the population, infant mortality, physical and mental health, the quality of healthcare and access to healthcare services, and the use of improved drinking water sources and sanitation facilities. The workforce and employment pillar evaluates talent, knowledge and training, as well as how many people among working-age population are able to participate in the labor force. The enabling environment pillar measures the environment that contributes to human capital development such as infrastructure, social mobility and legal framework and barriers (the Human Capital Index 2013, 2013, pp. 4-8)

The Human Capital Index 2015, the second addition, focuses on analyzing issues that contribute to education policies and improving workforce planning. Today many countries' economies have become more "knowledge-based technology-driven and globalized, and because we simply don't know what the jobs of tomorrow will look like" (p. 3). Governments recognize that the next generation should be more capable and competitive. The Human Capital Index serves to help various stakeholders understand the complexity of education and workforce dynamics, so they can make better decisions. Human capital is crucial for economic productivity as well as for social, civic, and political institutions. Recognition of current situation and capability of human capital is important to distinct stakeholders. The Index ranks countries and gives opportunities for them to compare economic performance. The Human Capital Index 2015 relies on three underlying concepts such as learning and employment outcomes, demographics, and measuring countries "distance to the ideal" state. The Index is designed for helping government entities, education institutions, business, and civil society organizations determine key problem areas to focus, invest, and improve them (the Human Capital Index 2015, 2015, pp. 3-4).

The Human Capital Report 2016 combines "international statistics, qualitative perception data and big data metrics" to draw a realistic picture of the situation with human capital nowadays and forecast the job opportunities for the future. The Index evaluates the level of education, skills and employment for people in five different age groups, from under 15 years to over 65 years. The aim is to analyze the past and present human capital capacity and suggest what talent will be more in demand in the future. The internet has become pervasive and it connects a global labor market. This gives opportunities for millions of people to engage more with digital platforms to access the global labor market. Now in an era when work is global, this new jobs horizon can enhance opportunities for developing countries to overcome technological phases (The Human Capital Report 2016, 2016, p. 1-2).

Therefore, the literature review section discussed the importance of human capital on economic growth. It deliberated the questions of the human capital measurement and main factors that can influence human capital such as school attainment and cognitive skills assessment. The paper determined that skilled workforce improves productivity and 


\section{Macrothink}

Journal of Public Administration and Governance

ISSN 2161-7104

2017, Vol. 7, No. 3

technology. The paper also explored The Human Capital Index, its measurement, goals and relation with the labor force. In the next section, the paper will examine the Human Development Index of Kazakhstan, Singapore, Korea and Malaysia and the relationship between human capital and economic growth.

\section{Data and Analysis}

Due to the lack of sufficient data for Human Capital Index, (the data is available for only three years) to assess the human capital of Kazakhstan, Singapore, Korea, and Malaysia I use the Human Developments Index (HDI) for 1980-2014 years created by the United Nations Development Program.

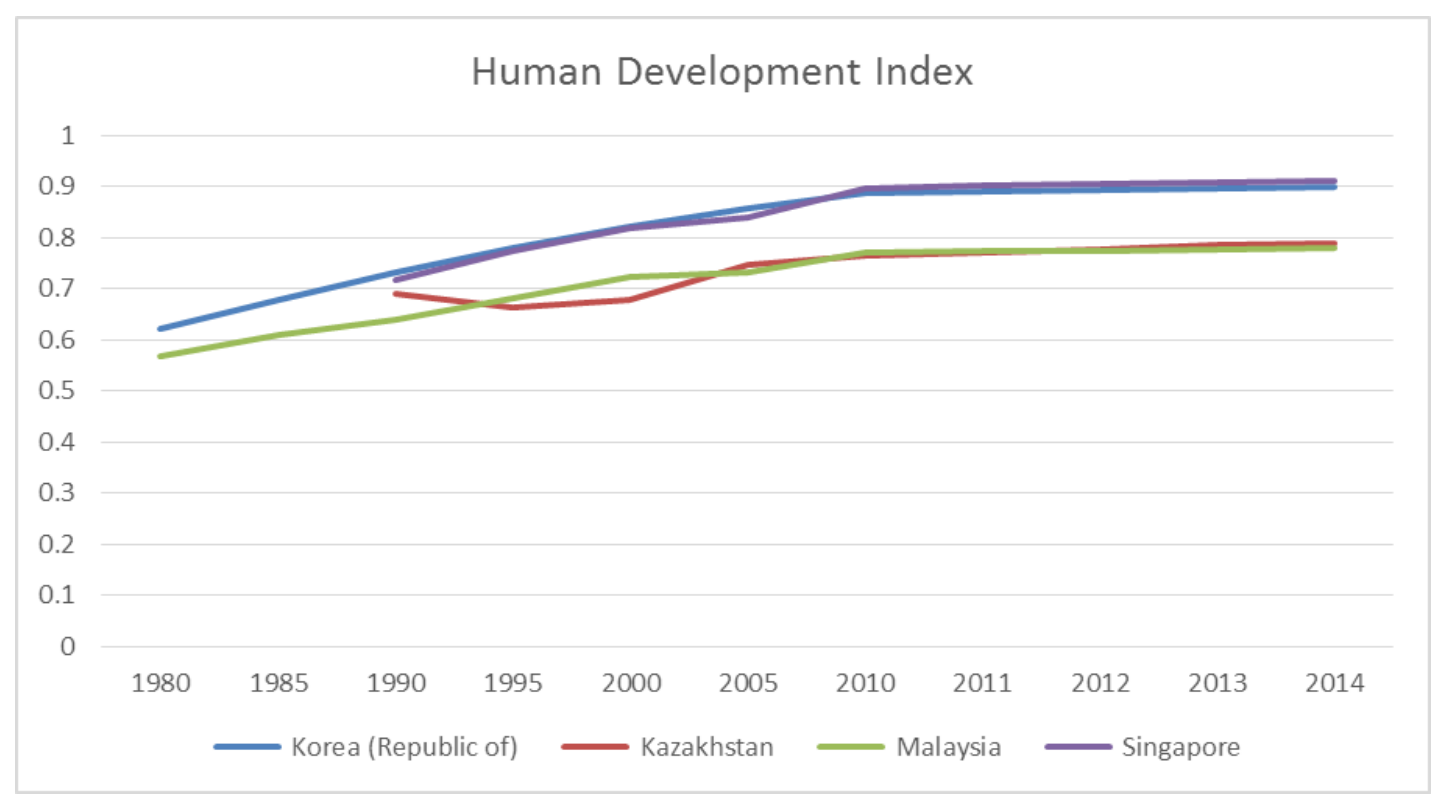

Graph 1. Human Development Index.

Source: Human Developments Reports. United Nations Development Program.

As illustrated in Graph 1 above, HDI ranks social and economic development of countries from 1980-2014. It consists of four components: life expectancy, mean years of schooling, expected years of schooling and gross national income per capita. Kazakhstan and Malaysia rank as countries with high HDI while Singapore and Korea are referred to the countries with very high HDI.

The indicator for the economic growth serves the GNI per capita (purchasing power parity) of the countries collected by the World Bank. 
Graph 2. GNI per capita, PPP.

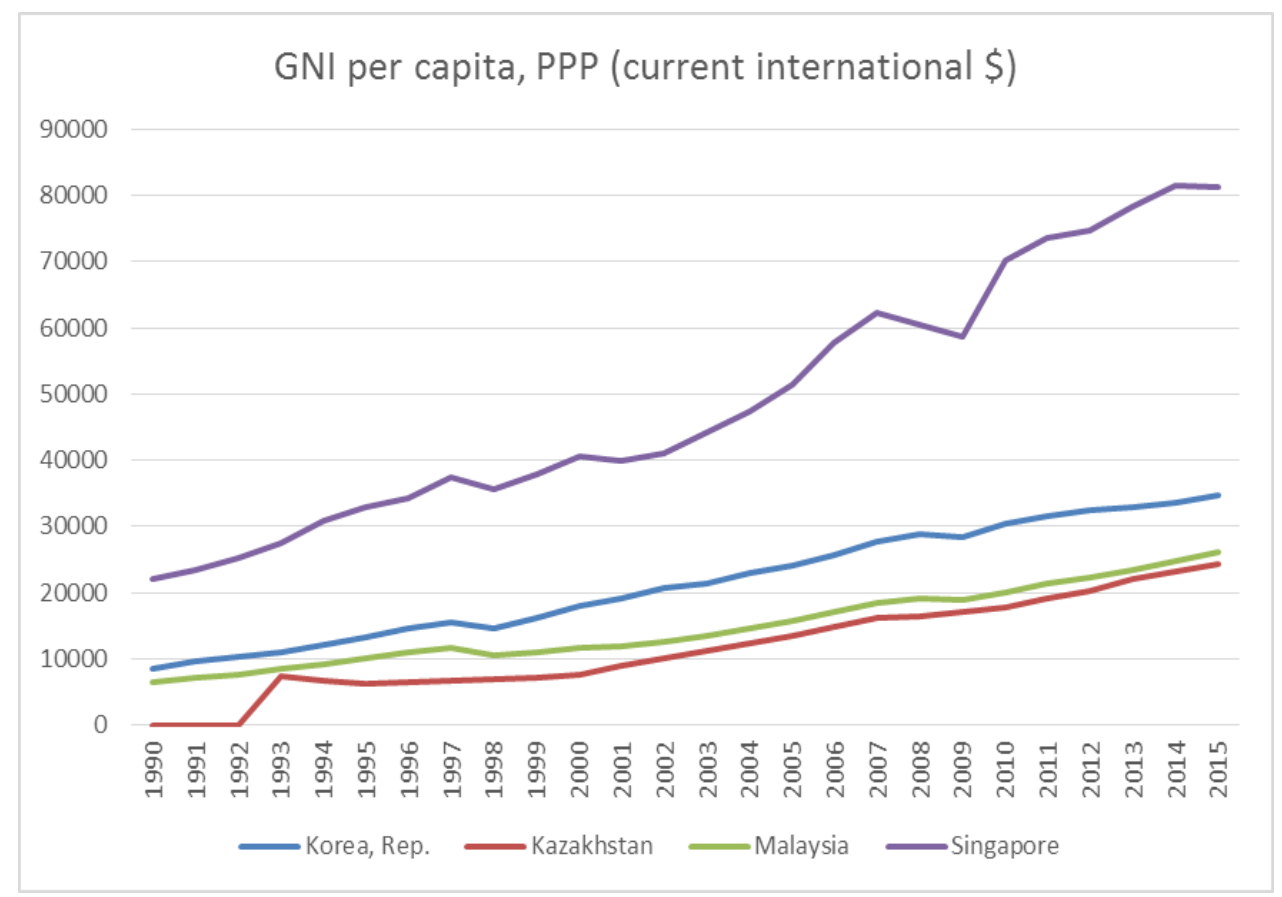

Source: World Data Bank of the World Bank

The Kazakhstan's mean of the GNI per capita (PPP) across 1990-2015 is the lowest among four countries. Graph 2 demonstrates rapid growth of the GNI per capita for Singapore from 1990 till 2015 and steady positive tendency for growth for Korea and Malaysia.

The regression analysis (Table 1) shows the strong correlation between HDI and GNI per capita. The estimation suggests that a one-percentage point increase in HDI leads to a 217,433 percent increase in the country's GNI per capita.

Table 1. Stata Output for Simple Regression

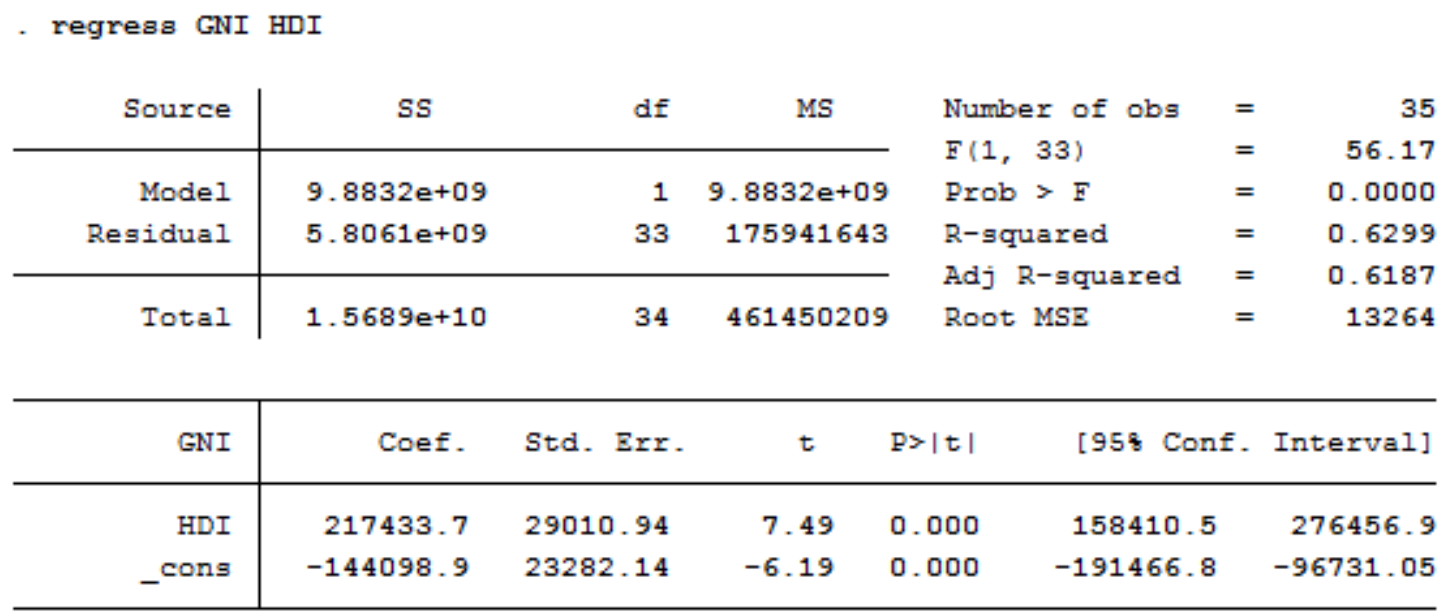

Also, Graph 3 below represents a positive correlation between two variables with a 95 


\section{Macrothink}

Journal of Public Administration and Governance

percent confidence interval that the increase in HDI undoubtedly entails the growth of GNI per capita.

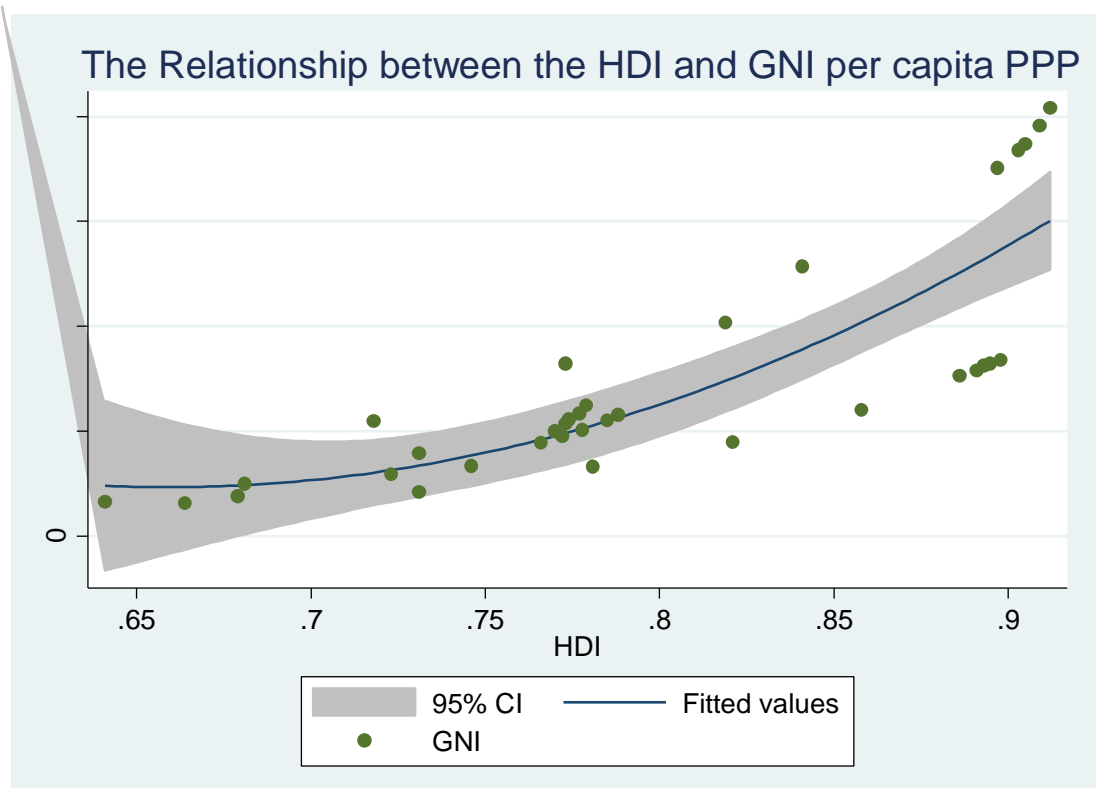

Graph 3. The relationship between Human Development Index and GNI per capita PPP.

\section{Education Development of Korea, Singapore, and Malaysia}

According to Moon \& Mun (2016), the efficiency of human capital is directly related to education, which itself is highly significant to the development of a country. Because many studies on East Asian economies, support the human capital theory, this section aims to analyze the education development of Singapore, Korea, and Malaysia and its effect to the economic growth.

\section{Korea}

Since the 1950s South Korea has become a high-tech industrialized economy and has demonstrated fabulous economic growth and integration between countries. In the 1950s and 1960s, Korea was a poor country with high unemployment and with low income and unskilled labor (Abizadeh, \& Yousefi, 1998, p. 689-690). Over the period 1960-2000, South Korea entered the "trillion-dollar club of world economies". Many scholars emphasize educational development in Korea as a center factor that contributed to economic and societal development. Korea gradually achieved a high level of universal enrollment at the elementary, middle and high school levels from 1960-1980. In 1950, Korea only had 10 higher education institutions, but by 2010, Korea had over 200 (Education for All 2015 National Review Report: Republic of Korea, 2015, p. 5).

The abundance of studies confirmed that education contributed to economic development in Korea. There is a visible relationship between education development and industrial development over the past forty years. For instance, elementary education contributed to improvements in light industry in the 1960s and early 1970s. Secondary education was important for heavy and chemical industry in the 1970s and in the early 1980s. Higher 
education became critical for technology-based industry that emerged in the 1980s and 1990s. Graduate education contributed to the knowledge-based economy in the late 1990s (Shin, 2012, p. 68).

In the 1990s, due to globalization Korean policy started to transform towards high-tech industry. In the late $1990 \mathrm{~s}$ and the $2000 \mathrm{~s}$, the government moved "towards knowledge production and national competitiveness in high-tech areas." Korea started to increase rapidly its investments in research and development (R\&D). Between 1990 and 2008 about 20 times more articles were published (1,382 articles in 1990 compared with 26,690 in 2008) (Shin, 2012, p. 61).

Korea is known for its high quality and the quantity of tertiary education. The incremental approach was selected by the government for education improvement. Korea gradually developed from elementary, secondary education and further to graduate education. Private higher institutions played a major role in providing higher education service. The share of students who enrolled in universities is $80 \%$ and is the highest among the OCED countries (Shin, 2012, p.69).

\section{Singapore}

Singapore in 1995 had already been described as "the world's most successful economy" and regarded as "the most successful of East Asia's 'four dragons'," (Huff, W., 1995, p. 1421). Since 1960, the Singapore economy has sustained rapid economic growth. Among 107 countries, Singapore demonstrated the highest growth of economic performance during 1960- 2000. Sugimoto \& Sugimoto cited this phenomenon as an "economic miracle" (2011, p. 1).

Singapore obtained its independence in 1965 and the first twenty years the country had issues of surviving and building a nation out of immigrants. In that period, Singapore attracted labor-intensive industries and recruited enough teachers to provide education for the whole population and arm them with basic skills to make them employable in those industries. In 1985-2005, Singapore concentrated on improving the enrollment rate and reducing the dropout rate. In the period of shifting the country into a knowledge-based economy, in 1995-1999, the government focused on developing cognitive skills such as critical and creative thinking. The government also decentralized schools gave them more discretion to encourage innovation and provide free environment for students to satisfy their interests and aptitudes (EFA: Singapore, 2015).

The strategic educational program "Thinking Schools, Learning Nation" was adopted in order to create a progressively thinking nation and to improve the education system so that it will meet the challenges of the twenty first century. There was a methodology for improving the quality of interaction between teachers and students. The education system aimed to equip students with knowledge, skills and values so they would be prepared for the real life. Thus, education methods concentrated on critical thinking, developing understanding, and the ability to ask questions and try to find multiple solutions (EFA: Singapore, 2015).

Understanding that education is crucial for economic success, the government prepares 
students "by strengthening the applied education model in the country." Moreover, Singapore realizes that the economy becomes more competitive, complex, and dynamic, so the universities provide training that is relevant for particular industries, enhance career guidance, and pay attention to industrial research, innovation, and enterprise activities (EFA: Singapore, 2015).

\section{Malaysia}

The fact that Malaysia still has issues in its education system and that the economy is vulnerable to a fall in world commodity prices confirms the theory of influence of the human capital on economic growth.

Malaysia, a middle-income country, has shifted from being a producer of raw materials to being a diversified country. By attracting investments in finance, biotechnology, services, and high technology, Malaysia is aiming to achieve a high-income standard of living by 2020. The government is trying to reduce its dependence on exports and it boosts its domestic production of goods. However, the main part of the economy is still based on export of palm oil, electronics, rubber, and oil and gas. "Gross exports of goods and services constitute more than $80 \%$ of GDP. The oil and gas sector supplied about $29 \%$ of government revenue in 2014" (Sundaram \& Wee, 2013, p. 2).

Malaysia has made great improvements in education in different aspects including increased accessibility to pre-school, secondary and high school education, as well as extended opportunities to enroll in tertiary education. The Malaysian government has taken some measures to reduce inequities in accessing school, including designating programs for the local population and programs for poor students. Also the government has concentrated on narrowing the gap between urban and rural populations by modernizing educational facilities and attracting more qualified teachers. However, there are some issues with quality education as evidenced by the significant range of results of students' performance on national exams. There are still some issues in Malaysian education that the government needs to address such as reaching the small percentage of children who do not go to schools, creating opportunities for children with special educational needs, improving the quality of education, increasing government expenditures for education, and providing an equal access quality education for children from rural areas (EFA: Malaysia, 2015, p. 123-124).

\section{Economy and Education in Kazakhstan}

According to the Human Development Index, in 2005-2013 the adult and youth literacy rate in Kazakhstan reached a high of $99.8 \%$. At least $99.3 \%$ of the population has at least some secondary education. The dropout rate is the lowest at $0.7 \%$ (Table 2 ). 
Table 2. Education achievements

Literacy rate

Education quality

\begin{tabular}{|c|c|c|c|c|c|c|c|c|c|c|c|}
\hline \multirow[b]{2}{*}{$\begin{array}{l}\text { HDI } \\
\text { rank }\end{array}$} & \multirow[b]{2}{*}{ Country } & \multirow{2}{*}{$\begin{array}{c}\text { Adult } \\
\text { (\% ages } \\
15 \text { and } \\
\text { older }) \\
\end{array}$} & \multicolumn{2}{|c|}{$\begin{array}{c}\text { Youth } \\
\text { (\% ages } 15-24)\end{array}$} & \multirow{2}{*}{$\begin{array}{c}\begin{array}{c}\text { Population } \\
\text { with at least } \\
\text { some } \\
\text { secondary } \\
\text { education }\end{array} \\
\\
\text { (\% ages } 25 \\
\text { and older) } \\
\end{array}$} & \multirow{2}{*}{$\begin{array}{c}\begin{array}{c}\text { Primary school } \\
\text { dropout rate }\end{array} \\
\text { (\% of primary } \\
\text { school cohort) }\end{array}$} & \multicolumn{3}{|c|}{$\begin{array}{c}\text { Performance of 15-year-old } \\
\text { students }\end{array}$} & \multirow{2}{*}{$\begin{array}{c}\text { Pupil-teacher } \\
\text { ratio, } \\
\text { primary } \\
\text { school } \\
\text { (number of } \\
\text { pupils per } \\
\text { teacher) } \\
\end{array}$} & \multirow{2}{*}{ 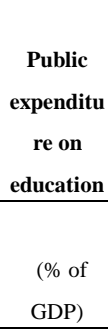 } \\
\hline & & & Female & Male & & & Reading & $\begin{array}{c}\text { Mathema } \\
\text { tics }\end{array}$ & Science & & \\
\hline & & $\begin{array}{l}2005-20 \\
13\end{array}$ & $\begin{array}{l}2005- \\
2013\end{array}$ & $\begin{array}{l}2005- \\
2013\end{array}$ & 2005-2013 & 2008-2014 & 2012 & 2012 & 2012 & $\begin{array}{l}2008- \\
2014\end{array}$ & 2005-2014 \\
\hline & VERY HIGH & J DEVEI & MENT & & & & & & & & \\
\hline 11 & Singapore & 96.4 & 99.8 & 99.8 & 77.4 & 1.3 & 542 & 573 & 551 & 17 & 2.9 \\
\hline 17 & Korea & .. & .. & .. & 82.9 & 0.8 & 536 & 554 & 538 & 18 & 4.9 \\
\hline 56 & Kazakhstan & 99.7 & 99.9 & 99.8 & 99.3 & 0.7 & 393 & 432 & 425 & 16 & 3.1 \\
\hline 62 & Malaysia & 93.1 & 98.5 & 98.4 & 68.2 & 0.9 & 398 & 421 & 420 & 12 & 5.9 \\
\hline
\end{tabular}

Source: Human Developments Reports. United Nations Development Program.

However, the results of assessment tests of Kazakhstan students in 2012 are low - 393 in reading, 432 in mathematics, 425 in science. While Singaporean students' performance is high - 542 in reading, 873 in mathematics, 551 in science. Likewise, Korean students' performance is also high with 536 in reading, 554 in mathematics, and 538 in science (Table 2). The low performance of the Kazakhstan students on the assessment tests is commensurate to the lowest GDP of Kazakhstan among four countries (the mean - \$16216.25) (Graph 2).

After establishing independence in 1991, Kazakhstan went from being a lower-middle-income country to one that was upper-middle-income country in less than two decades. The country moved to the upper-middle-income group in 2006. Since 2002, GDP per capita has risen six times and the level of poverty has fallen significantly. The economy of the country is based on the extraction and export of its natural resources. "The country's oil reserves are the ninth largest in the world, and hydrocarbon output was the equivalent of nearly $18 \%$ of GDP and about $60 \%$ of exports in 2015." The government of Kazakhstan aims to transform its economy from one relying on natural resource to one that is multi-sector and competitive. Despite enacted strategic development programs, it was difficult to achieve economic diversification due to the high price of oil. Kazakhstan has progressed in creating a less regulated, more transparent environmentally and more market-driven economy. Nevertheless, there are still some constraints related to the rule of law and governance that limit development of institutions, infrastructure, the investment climate, and investment in new technologies (The World Bank. 2015).

Kazakhstan had immense natural resources for economic growth, a skilled and low-cost labor force, a stable political system and a new business environment that is favorable to investment and growth. However, management factors was law and had not caught up with the rate of economic growth. The dissolution of the Soviet Union has destroyed the economy, and the 
production and distribution systems that had led to a hyper-inflation which reached 30 per cent per month by August 1994. This economic instability has created a fruitful environment for corruption in business practice. "Cites graft and bribery as being so widespread that even the Government has little control over them." Such a challenging environment became difficult for modern management education and development (Safavi, 1997).

The goal of management education and development of Kazakhstan is to prepare the population for efficient management of their resources. The country needs a human capital capable of understanding the tendency of a market economy to be able to manage it and successfully reforms the economy. The government needs training in business management for economics faculty and public servants. It also needs restructuring of the economics programs at all state universities. These measures are time-consuming and costly, so the government decided to establish a new school replicating the western management education and development systems (Safavi, 1997).

The Kazakhstan Institute of Management, Economics and Strategic Research (KIMEP) was established to offer an American-style MBA and a Master of Economics program in 1992 with a tuition fee of US $\$ 300$ for the academic year. The KIMEP graduates obtain a good understanding of business processes and are capable of implementing business strategies based on European and American standards. "They have developed analytical abilities, reasoning power, and the ability to communicate in English. They are well-prepared to engage in modern business practices in Kazakhstan." However, forty per cent of the graduates were invited to work for foreign corporations. Ten percent of KIMEP graduates were employed by local businesses and another ten per cent found work with the government (Safavi, 1997).

Many have criticized KIMEP as a university that has been sponsored by the EU and the US government and has trained skilled managers and professionals to further exploit Kazakhstan's energy and raw materials resources. It seemed true because the major investors from the EU and the US operated in Kazakhstan and concentrated their functions on depleting natural resources (Safavi, 1997).

One of the reasons why KIMEP graduates are employed in foreign firms is not only the salary. KIMEP graduates asserted that the inflexibility of the domestic work environment was not inviting for them. They were afraid that the local CEO will not be open to accept new ideas and will not create conditions for them to implement their knowledge of western education. Bingman (1992) noted in his research on government bureaucracy that "the intelligence and drive of the civil servants in Kazakhstan had been deliberately suppressed and their motivations perverted" (p. 32). Many examples of the graduates that are working for local organizations confirmed such unfriendly and closed environments.

The same situation with fellows of the international scholarship of the President of the Republic of Kazakhstan "Bolashak". More than 7,000 youth have completed education in western and south Asian universities, 2790 fellows continue education in the 27 countries on 77 specialties having highest priority for the country's economy (EFA: Kazakhstan, 2015, p. 30). However, they also are faced with a lack of understanding from the local authorities and reluctance to pay attention for new ideas to change. 
Notwithstanding the enormous efforts to establish a skilled management force in Kazakhstan, the number of well-prepared managers is not enough for the actual demand. The government should create a plan that forces all state universities to establish an effective modern business program during a very short period of time and to offer high quality education and training.

\section{Conclusion and Recommendations}

According to the Human Development Index 2016, Singapore and Korea are countries with a very high HDI while Kazakhstan and Malaysia are countries with a high HDI. Singapore's ranking is 11 , Korea's - 17, Malaysia - 62, Kazakhstan - 56. Thus, we can conclude that Kazakhstan is gradually increasing its human capital and shows better results than Malaysia. There is a gap between Kazakhstan, Korea and Singapore which means that Kazakhstan has potential for improvements.

In order to increase capacity of human capital for Kazakhstan Yusuf (2015) suggests the raising of awareness among national policymakers about the powerful growth effects of knowledge. He considers that Kazakhstan should develop its human capital to "turn Kazakhstan into a diversified, highly productive economy and to reach its goal of joining the top-30 developed countries by 2050." The Kazakhstan government should undertake measures for transitioning to a knowledge-based economy that includes long-term investments in education, the development of innovation capability, the modernization of the information infrastructure and the creation of a conducive economic environment (Sundac \& Krmpotic, 2011, p. 107).

Kazakhstan is a resource rich middle-income country and its path to an innovative economy that will perform long-run growth, production gains "depends upon success in raising the quality of human capital and extracting maximum mileage from a suitably tailored innovation system” (Yusuf, 2015, p. 258).

The quality of education needed for a modern knowledge economy is crucial. So, Kazakhstan has to first of all pay attention to teacher quality and the motivation that teachers bring to the table. This quality should have a linkage with training and qualifications, autonomy, and incentives. For instance, Singapore has the highest scores on the PISA and TIMSS tests, so the country attracts teachers from the best university graduates (Yusuf, 2015, p. 266).

Yusuf (2015) admits that to achieve such success in education is complicated. The country must constantly attract the best graduates into the teaching career, and create incentives to obtain the highest results from students. Only a few countries such as Korea and Singapore have had this practice. However, even though Korea and Singapore demonstrate perfect science and math scores, they are not completely happy with this high-pressure environment. Singapore had some serious challenges balancing mechanical learning with analytical thinking abilities while trying to inspire creativity. Notwithstanding, it is crucial for Kazakhstan to invest and follow the steps that these leaders in human capital implemented and put stress on human capital development. The foundation of an innovative system for the future is a student who is strong in science and mathematics, and equipped with communication, analytic, and soft skills (Yusuf, 2015, p. 265-266). 
Another catalyst of progress in education of Kakzahstan is development of high-quality research universities. Having Kazakhstan research universities connected with the private sector is a very important ingredient. Nazarbayev University is the first and only research university in Kazakhstan that was built in 2010. The Nazarbayev University should become a role model for other Kazakhstan universities, and will be a key component of an innovation system. Thus, to construct successful innovation system, Kazakhstan should equip Nazarbayev University with research capabilities that have world class standards, establish efficient connections with private entities; and provide comprehensive funding for innovative research (Yusuf, 2015, p. 279).

Development of an innovative economy will leads to the establishment of new workplaces. But there is a deficit of skilled workers experienced in new technology. There is unemployment even in other fields. For example, there are lot of teachers in humanity fields, while there is a requirement of teachers in natural sciences. Also, supply and demand of labor is satisfied in industry, agriculture, education, science and public health services. Kazakhstan is undergoing a lack of human capital in science and technology (Zhatkanbaev, 2008, p.109).

To improve human capital in Kazakhstan, Paul J. Davis, an Assistant Professor at the Kazakhstan Institute of Management, Economics and Strategic Research, suggests that many foreign workers employed in Kazakhstan mostly in health-care, oil and gas, education and financial services should train locals, transfer knowledge and oversee their learning the skill sets involved. The influence of foreign expertise and the dissemination of the best practices among the indigenous population, will be helpful to the government in achieving its goals.

There is also a gap in human-resource management development in Kazakhstan. There is a little awareness among local organizations about modern human-resource management practices. There is a significant problem in enhancing local human capital when trying to achieve government visions. For instance, Kazakhstan does not have a national human-resource association or institute while many other industrializing markets (Korea, Singapore, and Malaysia) have well-known associations. Moreover, the Kazakhstan work force is unfamiliar with the existence of international human resource conferences, though even if they know about it, it would be expensive for local human resource managers to travel abroad (Davis, 2012, p. 45).

Today the number of human resource specialists is low. For instance, there is a Kazakhstan human resource group on LinkedIn, the network for professionals. There are only 513 members in the group even though LinkedIn in Kazakhstan started four years ago (LinkedIn, 2012). KIMEP University established a human resource club where about twenty-five specialists from local businesses gather from to time to communicate and hear presentations. It is only an example of providing activities to strengthen human resource capacity in Kazakhstan (Davis, 2012, p. 45).

Moreover, it is worth noting that literature about human resource management in Kazakhstan is rudimentary as well as human-resource management thinking and practice. "HR is also isolated both within and outside the country." Kazakhstan requires a skilled and knowledgeable labor force for achieving sustained economic growth. The government also 
needs to critically increase expertise, connections and coordination of human resource management professionals in the country by giving opportunities to develop and transfer practices. Human resource management professionals should exercise western and western and South Asian policies and practices in order to maximize the capacity of nation's human capital. Unfortunately, the problem is that people are incompetent and are not concerned about these issues. "However, without a monumental change in direction, the strategic plans and proclamations will likely remain rhetoric and much promise will go unfulfilled" (Davis, 2012, p. 45-46).

Therefore, it is crucial for Kazakhstan to develop its human capital in order to turn the country into a diversified, highly productive economy and to reach its goal of joining the top-30 developed countries in the world.

\section{References}

Abizadeh, \& Yousefi. (1998). An empirical analysis of South Korea's economic development and public expenditures growth. Journal of Socio-Economics, 27(6), 687-700. https://doi.org/10.1016/S1053-5357(99)80003-1

Alfaro, L., \& Ketels, C. (2016). Singapore's Higher Education Cluster. Microeconomics of Competitiveness.

Retrieved

from:

http://www.isc.hbs.edu/resources/courses/moc-course-at-harvard/Documents/pdf/student-

rojects/Singapore\%20Higher\%20Education\%202016.pdf

Bean, C. (March 2016). Independent Review of UK Economic Statistics.

Bingman, C. F. (1992). Reinventing Government in Kazakhstan. The Public Manager, 21(3).

Education for All 2015 National Review Report: Republic of Korea. (2015). Retrieved from: file://C:/Users/a.shaimerdenova/Desktop/Korea\%20-\%20Education\%20for\%20All\%202015 \%20National\%20Review\%20229721E.pdf

Education for All 2015 National Review Report: Kazakhstan. (2015). Retrieved from: http://unesdoc.unesco.org/images/0022/002297/229717E.pdf

Education for All 2015 National Review Report: Malaysia. (2015). Retrieved from: http://unesdoc.unesco.org/images/0022/002297/229719E.pdf

Education for All 2015 National Review Report: Singapore. (2015). Retrieved from: http://unesdoc.unesco.org/images/0022/002298/229877E.pdf

Easterly, W., \& Levine, R. (2001). What have we learned from a decade of empirical research on growth? It's Not Factor Accumulation: Stylized Facts and Growth Models. World Bank Economic Review, 15(2), 177-219. https://doi.org/10.1093/wber/15.2.177

Glaeser, E., La Porta, L., Lopez-de-Silanes, R., \& Shleifer, F. (2004). Do Institutions Cause Growth? Journal of Economic Growth, 9(3), 271-303. https://doi.org/10.1023/B:JOEG.0000038933.16398.ed

Hanushek, E. A., \& Woessmann, L. (2011). The economics of international differences in 
educational achievement. In E. A. Hanushek, S. Machin, \& L. Woessmann (Eds.), Handbook of the economics of education, Vol. 3 (pp. 89-200). Amsterdam: North Holland. https://doi.org/10.1016/b978-0-444-53429-3.00002-8

Hanushek, E., \& Woessmann, A. (2012). Do better schools lead to more growth? Cognitive skills, economic outcomes, and causation. Journal of Economic Growth, 17(4), 267-321. https://doi.org/10.1007/s10887-012-9081-X

Hanushek, E. (2013). Economic growth in developing countries: The role of human capital. $\begin{array}{lllll}\text { Economics of } & \text { Education } & \text { 204-212. }\end{array}$ https://doi.org/10.1016/j.econedurev.2013.04.005

Human Developments Reports. United Nations Development Program. Retrieved from: http://hdr.undp.org/en/content/human-development-index-hdi

Huff, W. (1995). The developmental state, government, and Singapore's economic development since 1960. World Development, 23(8), 1421-1438. https://doi.org/10.1016/0305-750X(95)00043-C

Mallaby, S. (1995). Quick, quick, quick. (South Korea)(economic development and democracy). The Economist (US), 335(7917), S3.

Mincer, J. (1974). Schooling, experience, and earnings. New York: NBER.

Moon, H., \& Mun, Hwi-chang. (2016). The Strategy for Korea's Economic Success. Oxford University Press. https://doi.org/10.1093/acprof:oso/9780190228798.001.0001

Paul J. Davis. (2012). HR holds back economic development in Kazakhstan: ... and may thwart ambitions to be a top 50 nation by 2020. Human Resource Management International Digest, 20(6), 43-46. https://doi.org/10.1108/09670731211260924

Shin, J. (2012). Higher education development in Korea: Western university ideas, Confucian tradition, and economic development. Higher Education, 64(1), 59-72. https://doi.org/10.1007/s10734-011-9480-5

Safavi, F. (1997). The challenge of management education and development in Kazakhstan. $\left.\begin{array}{llllll}\text { Journal of } & \text { Management Development, } & 16(2 & 3\end{array}\right), \quad$ https://doi.org/10.1108/02621719710164328

Sugimoto, I., \& Sugimoto, I. (2011). Economic Growth of Singapore in the Twentieth Century Historical GDP Estimates and Empirical Investigations(Economic Growth Centre Research Monograph Series). Singapore: World Scientific Publishing Company. https://doi.org/10.1142/7858

Sundac, D., \& Krmpotic, I. (2011). Knowledge Economy Factors and the Development of Knowledge-based Economy. Croatian Economic Survey, 13(1), 105-141.

Sundaram, J., \& Wee, C. (2013). Malaysia@50 Economic Development, Distribution, Disparities. Singapore: World Scientific Publishing Company. https://doi.org/10.1142/9007 


\section{Macrothink}

Journal of Public Administration and Governance ISSN 2161-7104 2017, Vol. 7, No. 3

Overview of the country. The World Bank. Retrieved from: http://www.worldbank.org/en/country/kazakhstan/overview

UNESCO. (2006). Literacy for life: EFA Global monitoring report. Paris: UNESCO.

World Data Bank of the World Bank. Retrieved from: http://data.worldbank.org/indicator/NY.GNP.PCAP.PP.CD

Yusuf, S. (2015). Knowledge-based Economic Growth in Kazakhstan. Global Journal of Emerging Market Economies, 7(3), 257-286. https://doi.org/10.1177/0974910115592284

Zhatkanbaev, E. B. (2008). ECONOMIC DEVELOPMENT IN KAZAKHSTAN. Himalayan and Central Asian Studies, 12(3), 104-0_4. Retrieved from http://access.library.miami.edu/login?url=http://search.proquest.com/docview/1314949721?a ccountid $=14585$

\section{Copyright Disclaimer}

Copyright for this article is retained by the author(s), with first publication rights granted to the journal.

This is an open-access article distributed under the terms and conditions of the Creative Commons Attribution license (http://creativecommons.org/licenses/by/4.0/). 